Wicaksono, F. Y. · T. Nurmala · A.W. Irwan · A.S.U. Putri

\title{
Pengaruh pemberian gibberellin dan sitokinin pada konsentrasi yang berbeda terhadap pertumbuhan dan hasil gandum (Triticum aestivum L.) di dataran medium Jatinangor
}

\section{The effect of gibberellins and cytokinins concentration on growth and yield of wheat (Triticum aestivum L.) on medium land Jatinangor}

Diterima : 15 Februari 2016/Disetujui : 1 Maret 2016 / Dipublikasikan : Maret 2016

CDepartment of Crop Science, Padjadjaran University

\begin{abstract}
The objective of the research was to determine growth and yield of wheat that was planted on medium land Jatinangor which were treated gibberellins and cytokinins with the different concentrations. The experiment was conducted from March until August 2015 at The Experimental Station of Faculty of Agriculture, University of Padjadjaran, Jatinangor with an altitude of about 750 metres above sea level.The experimental design was used Randomized Block Design and treatment design was factorial which consisted of two factors and replicated three times. First factor was gibberellin concentration, consisted of levels 250 ppm, 350 ppm, and $450 \mathrm{ppm}$. Second factor was cytokinin concentration, consisted of levels 20 ppm, 40 ppm, and $60 \mathrm{ppm}$. Differences in the average value of two levels was tested by Duncan Multiple Range Test at 5\% significance level.The results of this research showed that there were interaction effect on growth components (plant height, number of tillerand leaf area index) and yield component (length of panicle) that indicated cytokinin concentrations could decrease gibberellin concentrations. Gibberellins and cytokinins had decreased number of grain because they trigger sterile grain.
\end{abstract}

Keywords: Wheat · Gibberellin · Cytokinin

Sari Penelitian ini bertujuan untuk mengetahui pertumbuhan dan hasil tanaman gandum yang maksimum di dataran medium melalui

\footnotetext{
Dikomunikasikan oleh Yudithia Maxiselly

Wicaksono, F. Y. · T. Nurmala ${ }^{1}$ A.W. Irwan · A.S.U.

Putri $^{2}$

1 Staf pengajar Program Studi Agroteknologi Fakultas

Pertanian Universitas Padjadjaran

2 Mahasiswa Program Studi Agroteknologi Fakultas

Pertanian Universitas Padjadjaran

Korespondensi: fywicaksono@yahoo.com
}

pemberian giberelin dan sitokinin dengan konsentrasi yang berbeda. Percobaan dilakukan sejak Maret hingga Agustus 2015 di Kebun Percobaan Fakultas Pertanian Universitas Padjadjaran, Jatinangor, dengan ketinggian tempat yaitu $\pm 750 \mathrm{~m}$ di atas permukaan laut.Rancangan percobaan adalah Rancangan Acak Kelompok dengan rancangan perlakuan faktorial. Perlakuan terdiri dari dua faktor, masing-masing terdiri dari tiga taraf,yang diulang tiga kali. Faktor pertama adalah konsentrasi giberelin, terdiri dari taraf 150 ppm, 250 ppm, dan 350 ppm. Faktor kedua adalah konsentrasi sitokinin, terdiri dari taraf 20, 40, dan 60 ppm. Perbedaan nilai rata-rata tarafdiuji dengan Duncan Multiple Range Test pada taraf nyata $5 \%$.Hasil penelitian menunjukkan bahwa terdapat interaksi terhadap komponen pertumbuhan (tinggi tanaman, jumlah anakan, dan indeks luas daun), dan komponen hasil (panjang malai) sehingga pemberian konsentrasi sitokinin dapat menurunkan konsentrasi giberelin. Giberelin dan sitokinin mengurangi jumlah biji karena memicu biji steril.

Kata kunci: Gandum · Giberelin · Sitokinin

\section{Pendahuluan}

Gandum merupakan makanan pokok kedua setelah beras di Indonesia. Gandum tidak tergantikan sebagai bahan baku tepung terigu karena memiliki kandungan gluten yang memberikan daya kembang adonan. Kebutuhan terigu di Indonesiapada tahun 2014mencapai 5,4 juta metrik ton. Kebutuhan terigu yang begitu besar dipasok dengan impor gandum sebesar 7,4 juta metrik ton yang menjadikan Indonesia sebagai importir gandum terbesar ke-4 dunia setelah 
Mesir, Cina, dan Brazil (Aptindo, 2014).Produksi gandum dalam negeri harus ditingkatkan agar dapat mengurangi impor gandum.

Tanaman gandum memiliki adaptasi yang baik di daerah tropis yang memiliki suhu rendah sehingga produksinya terbatas di dataran tinggi. Tanaman gandum kesulitan bersaing dengan komoditas hortikultura yang sebelumnya telah biasa dibudidayakan di dataran tinggi. Dataran medium, yaitu dataran dengan ketinggian 500-900 m dpl, sangat potensial untuk budidaya gandum karena mempunyai luas lahan pertanian yang lebih luas dibandingkan dataran tinggi. Penanaman gandum di lahan kering dataran medium mempunyai permasalahan dimana suhu lebih tinggi sehingga produksi gandum tidak optimal bahkan tanaman dapat terkena cekaman panas.

Giberelin adalah zat pengatur tumbuh yang berperan merangsang perpanjangan ruas batang, terlibat dalam inisiasi pertumbuhan buah setelah penyerbukan (terlebih jika auksin tidak berperan optimal), giberelin juga meningkatkan besaran daun beberapa jenis tumbuhan. Respons terhadap giberelin meliputi peningkatan pembelahan sel dan pembesaran sel. Pemberian giberelin sebanyak 250 ppm memberikan pertumbuhan dan hasil terbaik pada tanaman gandum kultivar dewata karena menunjukan bobot biji per malai dan bobot biji per tanaman tertinggi (Ariani et.al., 2014). Pemberian giberelin memberikan pengaruh yang nyata pada komponen pertumbuhan, juga memperpanjang umur tanaman, namun belum memuaskan pada hasil tanaman gandum.

Pavlista et.al. (2013) melakukan penelitian pada gandum musim dingin varietas standar dan semi kerdil dengan memberikan $\mathrm{GA}_{3}$, salah satu bentuk giberelin,sebanyak 0 ppm; 125 ppm; 250 ppm; 500 ppm dan 1000 ppm. Varietas standar pada umumnya lebih sensitif terhadap perlakuan $\mathrm{GA}_{3}$ dibandingkan varietas semi kerdil.Pemberian giberelin dengan konsentrasi 125 ppm dan 250 ppm memberikan peningkatan tinggi tanaman sebesar 10,92 $\mathrm{cm}$ dan $9,4 \mathrm{~cm}$ pada varietas standar. Varietas gandum semi kerdil yang diberikan aplikasi hormon giberelin sebesar 1000 ppm mendapatkan peningkatan tinggi tanaman sebesar $15,49 \mathrm{~cm}$.Pavlista et.al. (2013) melakukan penelitian kembali pada gandum varietas standar dan semi kerdil dengan memberikan perlakuan konsentrasi $\mathrm{GA}_{3}$ sebanyak 0-1.000 ppm pada berbagai suhu.
Varietas standar mencapai respon maksimum dengan 250 ppm sementara varietas semi kerdil mencapai respon maksimum pada 1000 ppm.Oleh karena itu, konsentrasi giberelin $\left(\mathrm{GA}_{3}\right)$ yang diberikan pada tanaman gandum yaitu 150 ppm; 250 ppm dan 350 ppm.

Pemberian sitokinin mungkin dapat melengkapi perlakuan $\mathrm{GA}_{3}$. Sitokinin dapat berfungsi untuk meningkatkan pembentukan anakan pada tanaman serealia, sehingga anakan dapat ditingkatkan (Pavlista et.al.,2013). Sakri et.al.(2009) melakukan penelitian terhadap dua kultivar gandum yaitu Mexipak dan Sham-3 yang diaplikasikan sitokinin dengan konsentrasi 0, 40, 80, dan 120 ppm. Hasil menunjukan pada pemberian sitokinin dengan konsentrasi $40 \mathrm{ppm}$ meningkatkan panjang daun bendera $17,10 \mathrm{~cm}$ lebih tinggi dibandingkan dengan kontrol, beserta persentasi protein dan karbohidrat yang lebih tinggi dibandingkan dengan kontrol. Menurut Poodineh et.al. (2013) pemberian sitokinin pada tanaman gandum kultivar Hamoon, memiliki dampak langsung pada proses pertumbuhan dan periode tumbuh gandum akan lebih lama, disebabkan penuaan daun tertunda, sehingga masa pertumbuhan lebih lama. Penyemprotan sitokinin dapat mengurangi kerusakan yang disebabkan karena kekeringan, menghindari penurunan jumlah anakan sekunder, meningkatkan hasil dan biomassa pada tanaman gandum.

Pemberian giberelin dan sitokinin masingmasing dapat menunda penuaan pada tanaman gandum sehingga umur pertumbuhan dapat berlangsung lebih lama yang menyebabkan hasil fotosintesis dapat diakumulasikan lebih banyak. Dengan demikian, diharapkan konsentrasi giberelin dapat dikurangi pada pemberian konsentrasi sitokinin tertentu.

Masalah yang dapat diidentifikasi dalam penelitian ini adalah apakah ada saling kebergantungan antara giberelin dan sitokinin dalam meningkatkan pertumbuhan dan hasil tanaman gandum di dataran medium.Manfaat penelitian ini adalah mengembangkan sains mengenai adaptasi tanaman gandum di dataran medium dengan beberapa rekayasa ekofisiologi.

Berdasarkan kerangka pemikiran, dapat dirumuskan hipotesis yaitu "pertumbuhan dan hasil tanaman gandum yang optimal pada kondisi panas di dataran medium dapat diperoleh dengan konsentrasi giberelin pada konsentrasi sitokinin yang tepat". 


\section{Bahan dan Metode}

Penelitian ini dilaksanakan di Kebun Percobaan Fakultas Pertanian Universitas Padjadjaran, Jatinangor, kabupaten Sumedang, Jawa Barat. Ketinggian tempat lokasi penelitian sekitar 750 $\mathrm{m}$ di atas permukaan laut (dpl), dengan tipe iklim C3 menurut klasifikasi Oldeman. Suhu rata-rata sekitar $23,2^{\circ} \mathrm{C}$. Jenis tanah di areal penelitian adalah Inceptisol dengan $\mathrm{pH}$ tanah 5,96. Penelitian dilaksanakan mulai Maret sampai dengan Agustus 2015.

Bahan yang akan digunakan dalam penelitian ini adalah benih gandum kultivar Dewata yang diproduksi oleh Fakultas Pertanian UKSW pada musim tanam 2014, GA (giberelin), benzil amino purin (sitokinin), pupuk majemuk NPK (15-15-15), pupuk urea $(45 \% \mathrm{~N})$, dan insektisida awal tanam yang mengandung bahan aktif karbofuran. Bahan pendukung yang lain adalah bahan untuk analisis kadar gluten, kadar protein, dan analisis tanah lengkap.

Peralatan budidaya yang dibutuhkan mulai dari persiapan lahan hingga panen adalah cangkul, kored, tugal, ember, tali, karung plastik dan peralatan penunjang lainnya. Peralatan lain yang digunakan adalah peralatan untuk pengamatan di lapang (meteran, klorofilmeter, termometer minimum-maksimum, dan ombrometer), peralatan dokumentasi, oven, dan timbangan. Sarana lain yang digunakan adalah peralatan laboratorium untuk analisis tanah dan peralatan laboratorium pascapanen untuk menganalisis kadar protein dan kadar gluten.

Penelitian ini menggunakan metode eksperimen yang dilakukan dalam lingkungan tidak terkendali. Rancangan percobaan adalah Rancangan Acak Kelompok dengan rancangan perlakuan faktorial. Perlakuan terdiri dari dua faktor, masing-masing terdiri dari tiga taraf,yang diulang tiga kali sehingga terdapat 27 plot percobaan. Faktor pertama adalah konsentrasi giberelin, terdiri dari taraf 150 ppm $\left(g_{1}\right), 250$ ppm $\left(g_{2}\right)$, dan 350 ppm $\left(g_{3}\right)$. Faktor kedua adalah konsentrasi sitokinin, terdiri dari taraf 20 ppm ( $\left.\mathrm{s}_{1}\right), 40$ ppm ( $\left.\mathrm{s}_{2}\right)$, dan 60 ppm ( $\left.\mathrm{s}_{3}\right)$. Petak kontrol dibuat untuk membandingkan penampilan tanaman dengan tanpa pemberian giberelin maupun sitokinin. Ukuran petak percobaan yang digunakan adalah $3 \mathrm{~m} \times 4 \mathrm{~m}$.

Aplikasi sitokinin dan giberelin dengan cara disemprot menggunakan knapsack sprayer. Volume semprot yang digunakan untuk penyemprotan bergantung pada luas kanopi tanaman, berkisar antara 0,6-1 L larutan per petak percobaan. Waktu penyemprotan giberelin adalah umur 4 mst dan 6 mst, sedangkan sitokinin 2 mst.

Pengamatan penunjang dilakukan untuk mengetahui suhu, kelembaban, dan curah hujan selama percobaan, serta umur berbunga dan umur panen. Pengamatan utama dilakukan untuk mengetahui komponen pertumbuhan, komponen hasil, dan hasil tanaman. Komponen pertumbuhan meliputi tinggi tanaman, jumlah anakan, kandungan klorofil, dan indeks luas daun. Masing-masing diamati pada umur $8 \mathrm{mst}$. Komponen hasil meliputi jumlah malai, panjang malai, jumlah biji per malai, bobot 100 biji, dan bobot biji per malai. Pengamatan hasil dilakukan pada bobot biji per tanaman.

Perbedaan nilai rata-rata taraf suatu faktor pada taraf faktor lain atau perbedaan nilai ratarata suatu taraf pada satu faktor secara mandiri diuji menggunakan Duncan Multiple Range Test pada taraf nyata 5\% (Gasperz, 1995).

\section{Hasil dan Pembahasan}

Berdasarkan pengamatan penunjang, kisaran suhu rata-rata selama percobaan adalah 23,0-23,4 ${ }^{\circ} \mathrm{C}$. Suhu selama percobaan melebihi suhu optimal tanaman gandum untuk pertumbuhan dan hasil tanaman gandum. Suhu yang tinggi disebutkan dapat mengurangi lamanya pengisian biji dan mengurangi berat biji (Wardlaw et al., 1989; Stone et al., 1995). Kelembaban selama percobaan berkisar antara 73-89 \%, sesuai dengan syarat tumbuh tanaman gandum. Curah hujan selama fase vegetatif (0 - 63hst) berkisar antara 1,7-7,4 $\mathrm{mm} /$ bulan, sedangkan fase generatif (63-133 hst) berkisar antara 0-0,1 mm/bulan. Kekurangan air selama fase generatif disuplai dari penyiraman.

Umur berbunga tanaman gandum yang diberi perlakuan giberelin dan atau sitokinin selama percobaan adalah 63 HST, sedangkan yang tidak diberi perlakuan giberelin dan atau sitokinin hanya 55 HST. Umur panen gandum yang diberi perlakuan giberelin dan atau sitokinin selama percobaan adalah 133 HST, sedangkan yang tidak diberi perlakuan giberelin dan atau sitokinin hanya 105 HST. Hal ini menunjukkan tanaman yang diberi giberelin dan atau sitokinin memiliki umur vegetatif yang lebih panjang dan tidak cepat menua. Giberelin maupun sitokinin berperan dalam pencegahan penuaan pada tanaman (Taiz and Zeiger, 2002). 
Tinggi tanaman pada umur 8 mst menunjukkan adanya interaksi antara konsentrasi giberelin dengan sitokinin (Tabel 1). Pemberian sitokinin sampai batas 40 ppm pada semua taraf giberelin meningkatkan tinggi tanaman. Pemberian giberelin sampai batas 250 ppm meningkatkan tinggi tanaman pada taraf sitokinin 20 ppm dan 40 ppm, tetapi tidak berbeda nyata pada taraf sitokinin 60 ppm. Tinggi tanaman yang tidak diberikan giberelin maupun sitokinin (kontrol) memiliki rata-rata $54,53 \mathrm{~cm}$. Bila dibandingkan dengan kontrol, tinggi tanaman yang diberi giberelin maupun sitokinin memiliki tinggi yang lebih panjang.

Tabel 1. Pengaruh konsentrasi giberelin dan sitokinin terhadap tinggi tanaman $(\mathrm{cm})$ pada umur 8 mst.

\begin{tabular}{cccc}
\hline \hline \multirow{2}{*}{ Giberelin } & \multicolumn{3}{c}{ Sitokinin } \\
\cline { 2 - 4 } & $\mathrm{s}_{1}$ & $\mathrm{~s}_{2}$ & $\mathrm{~s}_{3}$ \\
\hline $\mathrm{g}_{1}$ & $68,2 \mathrm{~A}$ & $77,2 \mathrm{a}$ & $70,3 \mathrm{a}$ \\
& $\mathrm{A}$ & $\mathrm{B}$ & $\mathrm{A}$ \\
$\mathrm{g}_{2}$ & $92,9 \mathrm{C}$ & $90,5 \mathrm{~b}$ & $73,6 \mathrm{a}$ \\
& $\mathrm{B}$ & $\mathrm{B}$ & $\mathrm{A}$ \\
$\mathrm{g}_{3}$ & $84,4 \mathrm{~B}$ & $89,7 \mathrm{~b}$ & $75,9 \mathrm{a}$ \\
& $\mathrm{B}$ & $\mathrm{B}$ & $\mathrm{A}$ \\
\hline \hline
\end{tabular}

$\overline{\text { Keterangan:nilai rata-rata yang diikuti oleh huruf }}$ besar yang sama (arah mendatar) dan huruf kecil yang sama (arah menurun) menunjukkan tidak berbeda nyata berdasarkan uji jarak berganda Duncan dengan taraf uji 5\%

Pemberian giberelin telah terbukti meningkatkan tinggi tanaman (Pavlista et.al., 2013). Sitokinin juga dapat meningkatkan tinggi tanaman dengan cara mendorong pemanjangan sel, karena sitokinin terbukti meningkatkan laju pemanjangan sel (Salisbury dan Ross, 1995). Pemberian konsentrasi giberelin akhirnya saling bergantung pada beberapa taraf konsentrasi sitokinin terhadap peningkatan tinggi tanaman, begitu pula sebaliknya. Aplikasi sitokinin dapat mengurangi konsentrasi giberelin, atau sebaliknya.

Konsentrasi giberelin dan sitokinin juga menunjukkan saling kebergantungan pada komponen jumlah anakan (Tabel 2). Jumlah anakan menurun pada taraf 40 ppm dan 60 ppm sitokinin bila dibandingkan 20 ppm sitokinin pada konsentrasi giberelin 150 ppm. Jumlah anakan meningkat setelah diberikan giberelin dengan konsentrasi 250 ppm pada semua taraf sitokinin. Jumlah anakan menurun kembali pada taraf 60 ppm sitokinin bila dibandingkan dengan 20 ppm sitokinin pada taraf giberelin 350 ppm.Jumlah anakan yang tidak diberikan giberelin maupun sitokinin (kontrol) memiliki rata-rata 13,9.

Tabel 2. Pengaruh konsentrasi giberelin dan sitokinin terhadap jumlah anakan 8 mst.

\begin{tabular}{cccc}
\hline \hline \multirow{2}{*}{ Giberelin } & \multicolumn{3}{c}{ Sitokinin } \\
\cline { 2 - 4 } $\mathrm{g}_{1}$ & $\mathrm{~s}_{1}$ & $\mathrm{~s}_{2}$ & $\mathrm{~s}_{3}$ \\
& $16.1 \mathrm{~b}$ & $12.6 \mathrm{a}$ & $14.7 \mathrm{a}$ \\
$\mathrm{g}_{2}$ & $\mathrm{C}$ & $\mathrm{A}$ & $\mathrm{B}$ \\
& $13.1 \mathrm{a}$ & $17.1 \mathrm{~b}$ & $18.8 \mathrm{~b}$ \\
$\mathrm{~g}_{3}$ & $\mathrm{~A}$ & $\mathrm{~B}$ & $\mathrm{C}$ \\
& $16.8 \mathrm{~b}$ & $16.4 \mathrm{~b}$ & $15.5 \mathrm{a}$ \\
\hline \hline
\end{tabular}

Keterangan:nilai rata-rata yang diikuti oleh huruf besar yang sama (arah mendatar) dan huruf kecil yang sama (arah menurun) menunjukkan tidak berbeda nyata berdasarkan uji jarak berganda Duncan dengan taraf uji 5\%

Sitokinin dapat berfungsi untuk meningkatkan pembentukan anakan pada tanaman serealia, sehingga anakan dapat ditingkatkan (Pavlista et.al., 2013). Giberelin juga dapat meningkatkan anakan tanaman serealia sampai batas tertentu (Niknejhad and Pirdashti, 2012). Sitokinin berinteraksi dengan giberelin, terbukti dari pemberian sitokinin akan mengurangi konsentrasi giberelin, begitu juga sebaliknya. Studi lanjut dibutuhkan untuk menganalisis mengapa pemberian konsentrasi sitokinin 60 ppmdan 350 ppm menurunkan jumlah anakan. Kemungkinan yang ada adalah konsentrasi yang lebih besar dapat meracuni tanaman (Taiz and Zeiger, 2002).

Interaksi antara sitokinin dan giberelin terjadi pada indeks luas daun (Tabel 3). Pemberian konsentrasi sitokinin sampai 40 ppm memberikan indeks luas daun tertinggi, kemudian menurun di konsentrasi sitokinin 60 ppm pada taraf konsentrasi giberelin 150 ppm. Pemberian konsentrasi sitokinin sampai 40 ppm tidak meningkatkan luas daun, malah menurun di konsentasi sitokinin 60 ppm pada taraf konsentrasi giberelin 250 ppm. Pemberian konsentrasi sitokinin sampai 60 ppm menurunkan indeks luas daun pada taraf konsentrasi giberelin 250 ppm. Indeks luas daun tanaman yang tidak diberi giberelin dan sitokinin $(1,84)$ lebih rendah dibandingkan tanaman yang diberi giberelin dan atau sitokinin.

Giberelin dan sitokinin secara mandiri dapat meningkatkan indeks luas daun. Giberelin dapat meningkatkan luas daun (Salisbury dan Ross, 1995) yang merupakan pembilang indeks luas daun. Sitokinin meningkatkan indeks luas 
daun dengan cara meningkatkan jumlah anakan (Niknejhad and Pirdashti, 2012), sehingga luas daun bertambah besar. Penambahan konsentrasi sitokinin dapat mengurangi konsentrasi giberelin pada indeks luas daun karena sitokinin dan giberelin masing-masing dapat meningkatkan indeks luas daun. Pemberian giberelin pada taraf $350 \mathrm{ppm}$ dan sitokinin pada taraf $60 \mathrm{ppm}$ memiliki indeks luas daun terkecil. Hal ini diduga karena tanaman mengalami keracunan (Taiz and Zeiger, 2002).

Tabel 3. Pengaruh konsentrasi giberelin dan sitokinin terhadap indeks luas daun

\begin{tabular}{cccc}
\hline \hline \multirow{2}{*}{ Giberelin } & \multicolumn{3}{c}{ Sitokinin } \\
\cline { 2 - 4 } $\mathrm{g}_{1}$ & $\mathrm{~s}_{1}$ & $\mathrm{~s}_{2}$ & $\mathrm{~s}_{3}$ \\
& $2.2 \mathrm{a}$ & $3.1 \mathrm{~A}$ & $2.7 \mathrm{~B}$ \\
$\mathrm{~g}_{2}$ & $\mathrm{~A}$ & $\mathrm{C}$ & $\mathrm{B}$ \\
& $3.4 \mathrm{~b}$ & $3.5 \mathrm{~B}$ & $3.1 \mathrm{C}$ \\
$\mathrm{g}_{3}$ & $\mathrm{~B}$ & $\mathrm{~B}$ & $\mathrm{~A}$ \\
& $3.5 \mathrm{~b}$ & $3.1 \mathrm{~A}$ & $1.9 \mathrm{a}$ \\
& $\mathrm{C}$ & $\mathrm{B}$ & $\mathrm{A}$ \\
\hline \hline
\end{tabular}

Keterangan:nilai rata-rata yang diikuti oleh huruf besar yang sama (arah mendatar) dan huruf kecil yang sama (arah menurun) menunjukkan tidak berbeda nyata berdasarkan uji jarak berganda Duncan dengan taraf uji 5\%

Tidak terdapat interaksi antara giberelin dan sitokinin terhadap kandungan klorofil. Pemberian sitokinin dan giberelin juga tidak memberikan pengaruh yang nyata terhadap kandungan klorofil (Tabel 4). Hal ini diduga sitokinin dan giberelin lebih berperan dalam pembentukan anakan dan luas daun. Kandungan klorofil pada kontrol $(16,5)$ lebih rendah dibandingkan tanaman yang diberi giberelin dan sitokinin. Sitokinin dan giberelin secara mandiri dapat meningkatkan kandungan klorofil karena menahan daun dari penuaan (Taiz and Zeiger, 2002).

Tabel 4. Pengaruh Konsentrasi Giberelin dan Sitokinin terhadap Kandungan Klorofil Umur 8 mst.

\begin{tabular}{cc}
\hline \hline Perlakuan & Kandungan Klorofil (CCI) \\
\hline $\mathrm{g}_{1}$ & $17.5 \mathrm{a}$ \\
$\mathrm{g}_{2}$ & $18.0 \mathrm{a}$ \\
$\mathrm{g}_{3}$ & $17.3 \mathrm{a}$ \\
$\mathrm{s}_{1}$ & $17.7 \mathrm{a}$ \\
$\mathrm{s}_{2}$ & $18.5 \mathrm{a}$ \\
$\mathrm{s}_{3}$ & $16.5 \mathrm{a}$ \\
\hline \hline
\end{tabular}

Keterangan:nilai rata-rata yang diikuti oleh huruf yang sama menunjukkan tidak berbeda nyata berdasarkan uji jarak berganda Duncan dengan taraf uji $5 \%$
Pemberian konsentrasi giberelin dan sitokinin tidak berpengaruh nyata terhadap beberapa komponen hasil, yaitu jumlah malai, jumlah biji per malai, bobot 100 butir, dan bobot biji per malai (Tabel 5).

Tabel 5. Pengaruh konsentrasi giberelin dan sitokinin terhadap jumlah malai, jumlah biji per malai, bobot 100 butir, dan bobot biji per malai

\begin{tabular}{ccccc}
\hline \hline Perlakuan & $\begin{array}{c}\text { Jumlah } \\
\text { malai }\end{array}$ & $\begin{array}{c}\text { Jumlah } \\
\text { biji per } \\
\text { malai }\end{array}$ & $\begin{array}{c}\text { bobot } \\
\text { (0) butir } \\
(\mathrm{g})\end{array}$ & $\begin{array}{c}\text { bobot } \\
\text { biji per } \\
\text { malai }(\mathrm{g})\end{array}$ \\
\hline $\mathrm{g}_{1}$ & $12.8 \mathrm{a}$ & $12.4 \mathrm{a}$ & $3.4 \mathrm{a}$ & $0.4 \mathrm{a}$ \\
$\mathrm{g}_{2}$ & $12.6 \mathrm{a}$ & $12.8 \mathrm{a}$ & $3.6 \mathrm{a}$ & $0.4 \mathrm{a}$ \\
$\mathrm{g}_{3}$ & $12.3 \mathrm{a}$ & $13.1 \mathrm{a}$ & $3.4 \mathrm{a}$ & $0.4 \mathrm{a}$ \\
$\mathrm{s}_{1}$ & $11.6 \mathrm{a}$ & $12.7 \mathrm{a}$ & $3.5 \mathrm{a}$ & $0.4 \mathrm{a}$ \\
$\mathrm{s}_{2}$ & $13.2 \mathrm{a}$ & $12.5 \mathrm{a}$ & $3.5 \mathrm{a}$ & $0.4 \mathrm{a}$ \\
$\mathrm{s}_{3}$ & $12.8 \mathrm{a}$ & $13.0 \mathrm{a}$ & $3.3 \mathrm{a}$ & $0.5 \mathrm{a}$ \\
\hline \hline
\end{tabular}

Keterangan:nilai rata-rata yang diikuti oleh huruf yang sama menunjukkan tidak berbeda nyata berdasarkan uji jarak berganda Duncan dengan taraf uji 5\%

Giberelin dan sitokinin telah disebutkan di atas dapat mempengaruhi jumlah anakan, tetapi tidak mempengaruhi pembentukan malai. Pembentukan malai gandum dipengaruhi oleh partisi fotosintat yang tersedia di tanaman dan waktu pembentukan anakan (Cai, et.al., 2014). Bobot 100 butir juga dipengaruhi oleh partisi fotosintat sehingga tidak berbeda nyata. Pemberian giberelin dan sitokinin ternyata mempengaruhi jumlah biji per malai yang lebih rendah dibandingkan deskripsi varietas (47 butir). Hal ini disebabkan pemberian giberelin dapat menyebabkan biji steril atau tidak ada pembentukan biji (Taiz and Zeiger, 2002). Efek yang sama juga dijelaskan pada tanaman padi (Liu et.al., 2011). Jumlah biji per malai yang rendah menyebabkan bobot biji per malai juga rendah sehingga pemberian giberelin sebaiknya dilaksanakan setelah tanaman berbunga.

Interaksi giberelin dan sitokinin hanya terjadi pada panjang malai (Tabel 6). Pemberian konsentrasi sitokinin 40 ppm memberikan panjang malai yang tidak berbeda dengan konsentrasi sitokinin 20 ppm dan 60 ppm, tetapi konsentrasi sitokinin 60 ppm memberikan malai yang lebih panjang dibandingkan konsentrasi sitokinin 20 ppm Pada taraf konsentrasi giberelin 150 ppm. Pemberian konsentrasi sitokinin tidak memberikan perbedaan panjang malai pada taraf konsentrasi giberelin $250 \mathrm{ppm}$. Pemberian konsentrasi sitokinin menurunkan panjang malai pada taraf konsentrasi giberelin 350 ppm. 
Tabel 6. Pengaruh konsentrasi sitokinin dan giberelin terhadap panjang malai

\begin{tabular}{cccccccc}
\hline \hline \multirow{2}{*}{ Giberelin } & \multicolumn{9}{c}{ Sitokinin } & & \\
\cline { 2 - 8 } & \multicolumn{3}{c}{$\mathrm{s}_{1}$} & \multicolumn{3}{c}{$\mathrm{s}_{2}$} & \multicolumn{3}{c}{$\mathrm{s}_{3}$} \\
\hline $\mathrm{g}_{1}$ & 7.8 & $\mathrm{a}$ & 8.2 & $\mathrm{a}$ & 8.4 & $\mathrm{~b}$ \\
& $\mathrm{~A}$ & & $\mathrm{AB}$ & & $\mathrm{B}$ & \\
$\mathrm{g}_{2}$ & 8.3 & $\mathrm{~b}$ & 8.3 & $\mathrm{a}$ & 8.6 & $\mathrm{~b}$ \\
& $\mathrm{~A}$ & & $\mathrm{~A}$ & & $\mathrm{~A}$ & \\
$\mathrm{~g}_{3}$ & 9.0 & $\mathrm{c}$ & 8.1 & $\mathrm{a}$ & 7.7 & $\mathrm{a}$ \\
& $\mathrm{B}$ & & $\mathrm{A}$ & & $\mathrm{A}$ & \\
\hline \hline
\end{tabular}

Keterangan:nilai rata-rata yang diikuti oleh huruf besar yang sama (arah mendatar) dan huruf kecil yang sama (arah menurun) menunjukkan tidak berbeda nyata berdasarkan uji jarak berganda Duncan dengan taraf uji 5\%

Sitokinin berfungsi dalam pembelahan sel (Taiz and Zeiger, 2002) sehingga ukuran malai dapat bertambah besar. Giberelin berfungsi dalam pembesaran sel (Taiz and Zeiger, 2002) sehingga ukuran malai juga dapat bertambah besar. Peningkatan konsentrasi sitokinin dapat mengurangi konsentrasi giberelin pada komponen jumlah malai.

Tidak terdapat interaksi antara konsentrasi giberelin dan sitokinin terhadap bobot biji per tanaman. Konsentrasi giberelin dan sitokinin secara mandiri juga tidak berpengaruh terhadap hasil tanaman (bobot biji per tanaman) (Tabel 7).

Tabel 7. Pengaruh konsentrasi giberelin dan sitokinin terhadap bobot biji per tanaman.

\begin{tabular}{cc}
\hline \hline Perlakuan & bobot biji per tanaman $(\mathrm{g})$ \\
\hline $\mathrm{g}_{1}$ & $5.3 \mathrm{~A}$ \\
$\mathrm{~g}_{2}$ & $5.5 \mathrm{~A}$ \\
$\mathrm{~g}_{3}$ & $5.4 \mathrm{~A}$ \\
$\mathrm{~s}_{1}$ & $5.0 \mathrm{~A}$ \\
$\mathrm{~s}_{2}$ & $5.8 \mathrm{~A}$ \\
$\mathrm{~s}_{3}$ & $5.5 \mathrm{~A}$ \\
\hline \hline
\end{tabular}

Keterangan:nilai rata-rata yang diikuti oleh huruf besar yang sama (arah mendatar) dan huruf kecil yang sama (arah menurun) menunjukkan tidak berbeda nyata berdasarkan uji jarak berganda Duncan dengan taraf uji 5\%

Pemberian konsentrasi giberelin dan sitokinin tidak berpengaruh terhadap hasil tanaman karena komponen hasil tanaman banyak yang tidak dipengaruhi oleh giberelin dan sitokinin, terutama pada jumlah biji per malai. Jumlah biji per malai yang rendah menyebabkan bobot biji per malai dan bobot biji per tanaman menjadi rendah

\section{Kesimpulan dan Saran}

Terdapat interaksi terhadap komponen pertumbuhan (tinggi tanaman, jumlah anakan, dan indeks luas daun), dan komponen hasil (panjang malai) sehinggapemberian konsentrasi sitokinin dapat menurunkan konsentrasi gibe-relin. Giberelin dan sitokinin mengurangi jumlah biji karena memicu biji steril.

Penelitian lanjutan dapat dilakukan untuk mengetahui waktu pemberian giberelin dan sitokininuntuk mengurangi biji steril.

\section{Daftar Pustaka}

Aptindo. 2014. Overview Industri Tepung Terigu Nasional Indonesia. Seminar Aptindo, 11 Juli 2014. Jakarta

Ariani, E., F.Y. Wicaksono, A.W. Irwan, T. Nurmala, and Y. Yuwariah. 2015. Pengaruh berbagai pengaturan jarak tanam dan konsentrasi giberelin $\left(\mathrm{GA}_{3}\right)$ terhadap pertumbuhan dan hasil tanaman gandum (Triticum aestioum L.) kultivar dewata di dataran medium Jatinangor. Agric. Sci. J., 2(1): $31-52$

Cai, T., H. Xu, D. Peng, Y. Yin, W. Yang, Y. Ni, X. Chen, C. Xu, D. Yang, Z. Chui, and $\mathrm{Z}$. Wang. 2013. Exogenous hormonal application improves grain yield of wheat by optimizing tiller productivity. Field Crops Res., 155: 172 - 183.

Gasperz, V. 1995. Teknik Analisis dalam Penelitian Percobaan Edisi 1. Penerbit Tarsito. Bandung.

Liu, Y., W. Chen, Y. Ding, Q. Wang, G. Li, and S. Wang. 2011. Effect of gibberellic acid $\left(\mathrm{GA}_{3}\right)$ and a-naphtalene acetic acid (NAA) on the growth of unproductive tiller and the grain yield of rice (Oryza sativa L.). Afr. J. of Agr. Res., 7(4):534-539

Niknejhad, Y., and H. Pirdashti. 2012. Effect of growth simulators on yield and yield components of rice (Oryza sativa L.) ratoon. Int. Res. J. of App. \& Basic Sci., 3(7): 1417-21.

Pavlista, A.D., K. Santra, and D.D. Baltensperger. 2013. Bioassay of winter wheat for gibberellic acid sensitivity. Am. J. of Plant Sci., 4: 2015-2022

Poodineh, A. Mehraban, andA. Hosein. 2014. Effect of water stress and spraying cytokinin hormone on Hamoon wheat 
variety in Sistan region. Int. J. of Farming and Allied Sci. Vol. 4 (S4): 814-818.

Sakri, A. Faisal, dan S. A. Amin. 2009. The response of two wheat cultivars Triticum spp to cytokinin and water stress treatments and their interaction. J. of Zankoy Sulaimani, 12(1): 51-58.

Salisbury, F.B. dan C.W. Ross. 1995. Fisiologi Tumbuhan (Terj. D.R. Lukman). Penerbit ITB. Bandung.
Stone, P.J., R. Savin, I.F. Wardlaw, and M.E. Nicolas. 1995. The influence of recovery temperature on the effects of brief heat shock on wheat. I. Grain growth. Aus. J. Plant Physiol., 22: 945-954.

Taiz, L., and E. Zeiger. 2002. Plant Physiology, 3rd Ed. Sinauer Associates. Sunderland.

Wardlaw, I.F., I.A. Dawson and P. Munibic, 1989. The tolerance of wheat to high tempe-ratures during reproductive growth. II. Grain development. Aust. J. Agri. Res., 40: 1-13 